\title{
DOES THE QUALITY OF A PLACE AFFECT WELL-BEING?
}

\author{
FRANTIŠEK MURGAŠ, MICHAL KLOBUČNÍK
}

Department of Geography, Faculty of Science, Humanities and Education, Technical University of Liberec, Studentská 2, 46117 Liberec, Czech Republic; e-mail: frantisek.murgas@tul.cz

Department of Human Geography and Demography, Faculty of Natural Sciences, Comenius University of Bratislava, Mlynská dolina, 84215 Bratislava, Slovak Republic; e-mail: klobucnik@fns.uniba.sk

\begin{abstract}
Murgaš F., Klobučník M.: Does quality of place affect well-being? Ekológia (Bratislava), Vol. 35, No. 3, p. 224-239, 2016.

An important methodological question in the general discourses concerning the quality of life is scale and mutual relationship of its two dimensions. In this article, the subjective dimension is understood as well-being; data from its spatial differentiation in districts of the Czech Republic were obtained from a face-to-face interview. The objective dimension is understood from the geographical aspect as quality of a place; it is quantified by the indicators of the golden standard of quality of life. Data from its spatial differentiation in districts of the Czech Republic are secondary. The article aims to compare the data of well-being and quality of a place for all the districts, with a premise of a higher level of well-being in the districts with a higher quality of a place, and vice-versa. This would answer the question of whether the quality of a place affects well-being.
\end{abstract}

Key words: quality of life, good life, quality of a place, well-being, golden standard of quality of life.

\section{Introduction}

The concept of quality of life reflects one of the many interests of society that strives to capture the social and economic reality. It is also a multidimensional and quite difficult concept. One of the few common features in the research on quality of life in academic circles is the fact that it consists of two dimensions - a subjective one, in psychology, also known as well-being, and an objective dimension, without any consistent nomenclature yet. Each of the aforementioned dimensions is formed by several indicators that represent quantifiable variables and/or domains formed by groups of certain indicators. Geographers Murgaš and Klobučník (2014) refer to an objective dimension as a place, thus understanding the concept of quality of life as well-being and place. The quality of life is emotional and cognitive subjective evaluation, which is dependent on an individual's perception of a good or satisfactory life.

This paper aims to point out the influence that certain places might have on well-being. According to Easterlin (2015: 283), 'The term subjective well-being encompasses a variety of measures of feelings of well-being - happiness, life satisfaction, ladder-of-life which are 
treated here as interchangeable'. In this case, we do not refer to well-being as 'personal wellbeing' in order to distinguish it from another attributes (whether it is objective, psychological, financial, and so on) simply because we always understand well-being as a personal matter. As pointed out by Casas et al. (2004), the dimensions of quality of life are not equal and it is well-being that plays the most important role here.

The concept of quality of life in this respect can be linked with the notion of a good life, in other words, living life in a good place. Measuring a good life is a matter of subjective perception, and it emanates from the values and attitudes of individuals, while the gauge of the good place is rather more objective. When trying to evaluate a place, we examine its quality, which can be measured by means of a wide scope of demographic, social, economic, and environmental indicators as well as according to the amenities that can be found there.

Examining the districts of the Czech Republic, we attempt to answer the question how the quality of a place affects well-being. Together with other Central European countries, the Czech Republic has undergone a transformation process, affecting the political organisation, economic development, and even the division of a single state, which left a significant mark across whole spheres of social life. The process of these fundamental changes is often described as 'transition', which is why the former communist countries are often called transition countries. Among other things, these processes were carried out along with the re-establishment of the political, religious, and entrepreneurial freedom (Easterlin, 2009). The transition in the Czech Republic was even more pronounced since the country had historically belonged to the most developed Central and East European countries during the whole $20^{\text {th }}$ century. After 1989, at the beginning as a part of Czechoslovakia and later as an independent state, this process was, due to its intensity, often denoted as 'shock therapy'. According to World Value Survey (Rabušic, Hamanová, 2009), the Czech Republic reached the second highest value of life satisfaction from all transition countries between the years 1990-1993 (6.23) and 1999-2002 (7.06). Generally, it can be said that people are more satisfied with their life in those countries where the transition was faster and more intensive than their counterparts that were lagging behind (Sanfey, Teksoz, 2005). Nowadays, in the post-transitive period, the Czech Republic still occupies the top rank in the most important macro-economic data among the former communist states. According to Eurostat (2015), the unemployment rate in the Czech Republic was even the second lowest in EU reaching 4.9\%. (The lowest unemployment was in Germany.)

Several authors have done research on the influence of demographic, socio-economic, and political factors on the quality of a place from different perspectives (Lyubomirsky et al., 2005; Blatný, 2010; Sirgy, 2012). In our study, we build on the spatial analysis of 10 indicators, reflecting the quality of places across the districts in the Czech Republic.

This article aims to provide a thorough analysis of the quality of a place and its influence on well-being with the use of the Pearson coefficient of correlation by comparing data that quantifies the quality of a place on a district hierarchical level in the Czech Republic. Data were collected through face-to-face interviews. Data about the quality of a place are secondary data of 10 indicators that represent the golden standard of quality of life. The results point out some interesting features about the quality of a place and its influence on the overall wellbeing and outline certain correlations in terms of better well-being in the districts with the 
higher values of the quality of a place and vice-versa. Last but not least, this article contributes to the development of the methodological inquiry of the quality of life that lags behind the expansion of partial research.

\section{Theoretical framework and hypotheses}

Quality of life is the emotional and cognitive subjective evaluation dependent on an individual's perception of a good, satisfactory life. According to Murgaš (2009: 124), 'quality of life of an individual consists of somatic, psychological, religious, social and economic goods, leading into the subjective feeling of satisfaction or happiness - confronted with the health, socio-pathological, economic and environmental evils, while this confrontation takes place in spatially differentiated external environment'.

There are several reasons why it is important to deal with the quality of life. First of all, there is an ongoing discussion on the proposal of the Stiglitz commission to replace GDP (Gross Domestic Product) as a general measure of social and economic development with the quality of life; the discussion was in favour of this proposal (Stiglitz et al., 2010). In the medical context, a discussion has started on measuring the cost effectiveness in healthcare, concerning qualitative and quantitative assessment of life - quality-adjusted life years (QALY) or Disability-adjusted life years (DALY) (Rapley, 2008). In psychology, the research on the quality of life has led to the discovery of a new branch called positive psychology (Seligman, 2002). The latest acknowledgment of the concept of quality of life in public discourses was its incorporation into the 2015 Vatican encyclical Laudato si by Pope Francis (Francis, 2015).

When assessing the quality of our life, we assess how good our life is. This is especially studied by psychologists, who usually identify the subjective dimension of the quality of life with well-being. In this context, happiness has an independent status (Diener, Biswas-Diener, 2008; Dutt, Radcliff, 2009; Veenhoven, 2011). On the other hand, it is also true that we are not living in a vacuum, but in a particular place - settlement, region, and state. The geographical units of different hierarchical levels are significantly spatially differentiated. From the aspect of quality of life, geographers assess where life is good, and not only where there are good material and non-material conditions for life, but also where people who are satisfied with their lives reside. Since the turn of the new millennia, an increasing interest in the issue of quality of life can be recognised within Geography (Eyles, Williams, 2008; Rappaport, 2009; Aslam, Corrado, 2012; Davern, 2014). This trend is also reflected among the Slovak geographers, where the attention is paid to different aspects of quality of life, from the conceptualisation of this issue itself to the evaluation of an impact of floods on the quality of life: Andráško (2013), Angelovič (2013), Angelovič, Ištok (2016), Ira (2011, 2013, 2015), Ira et al. (2008), Jakubcová et al. (2016), Muchová, Petrovič (2010), Murgaš (2013, 2014, 2015), and Murgaš a Klobučník (2014). The objective dimension of the quality of life represents the quality of a place (Trip, 2007; Florida, 2012; Murgaš, Klobučník, 2016), while this place can have any hierarchical form in spatial terms, starting with an urban neighbourhood, municipality, city, region, and state and ending with a continent. When the media discuss the issue of the quality of life, whether it is in political or public discourse, the quality of life is usually identified with its objective, spatial dimension, and is measured as the quality of a place. 
The key phenomenon of an objective dimension is a good place as a spatial representation of where it is good to live. The quality of a place is measured by 10 indicators composing the golden standard of quality of life. The conceptualisation of the golden standard of quality of life is described by Murgaš and Klobučník (2016).

Because there is only one quality of life, validity of its research can only be achieved by a holistic approach to it. However, it holds true that its two main dimensions are not equivalent - well-being is more important (Casas et al., 2004). According Blatný (2010), well-being is quite simply defined as a long-term or continuing emotional state, which reflects the overall satisfaction of humans with their own lives.

The sources of well-being can be divided into four categories; the first ones are the sociodemographic and demographic factors (gender, age, education, marital status, economic status (income), and also employment, health, housing, faith, ethnicity or race). 'These variables (constituting the first category) explain according to different researches only $5-20 \%$ of the variance of well-being' (Blatný, 2010: 198). According to Lyubomirsky et al. (2005), well-being is $10 \%$ influenced by different circumstances, whether they are geographic, demographic, or social characteristics of the regions or individual historical development. Another $40 \%$ is comprised of intentional activities representing a wide scope of daily activities of people, and the last $50 \%$ of well-being is genetically determined.

Therefore, the key question for us is whether with an increasing quality of a place, the level of well-being also increases. Our hypothesis is that it does not. The raison dêtre of quality of life is, thus, an assessment of human life. As the distinctive feature of this concept is its dichotomy, we can talk about the quality of life in relation to the individual, and on the other hand, also in relation to the society as a societal quality of life. It is important that the quality of life does not emerge in a subjective and objective context, rather it is. The ability to assess one's own life is created in the process of personality development. The quality of life of a society, or societal quality of life, also is; it is created through the development of social relationships in the society and the development of its capitals - social, cultural, political, and symbolic. Just as for the quality of life of a human, it is true also for the societal, that its problem is a problem of values.

\section{Data}

In our analysis, data for 77 districts in the Czech Republic were analysed. The first group of data comprises primary variables characterising well-being. These data were obtained through face-to-face interviews conducted in 2014. The sample consists 1797 persons over 15 , which can be considered as a representative sample of the population over 15 in the Czech Republic. Out of the total number of respondents, $48.6 \%$ were men (874) and $51.4 \%$ women (923). In terms of relative abundance, there was deviation from the sample of only $0.1 \%$; a similar deviation was measured from the perspective of regional representation.

The second group of data comprises data forming the golden standard of quality of life (Murgaš, Klobučník, 2016). This group consists of secondary data obtained from the statistical sources. This consists of 10 indicators: suicide rate, life expectancy at birth - males, life expectancy at birth - females, mortality, birth rate and divorce rate, population with tertiary 
education, unemployment rate, emission balance, and generativity. All the aforementioned data were provided by the Czech Statistical Office, with the exception of emission balance (the data were provided by the Czech Hydro meteorological Institute) and generativity ${ }^{1}$. Blood donation was used as its expression; data were provided by the Institute of Health Information and Statistics of the Czech Republic. The data are from 77 districts of the Czech Republic for 2001-2011. All indicators have been assigned the same weight. The values of the golden standard of quality of life for individual districts are compared with the data about well-being obtained in the autumn of 2014 also for the individual districts. The sample consisted of 1797 individuals older than 15 years, which is a representative sample of the population of the Czech Republic over the age of 15 . Of these, $48.6 \%$ were men (874) and $51.4 \%$ women (923). In terms of relative frequency, we detected a deviation of the sample within the range $0.1 \%$; the same deviation of the sample within the range $0.1 \%$ was recorded also in terms of regional representation.

The application of tests of statistical significance in the $2^{\text {nd }}$ degree of sorting was limited by the smaller number of observations in the extreme values of the scale $(n=12)$, which has weakened the strength of the tests of significance. Therefore, in the following interpretation, each calculated value will have an attached number of cells of a contingent table, in which an insufficient number of observations were detected. The value of the testing criterion $\left(\mathrm{X}^{2}\right)$ was calculated using the correction.

It can be stated that there is a decrease in life satisfaction in relation to age, the age groups were $15-19$ years, $20-24,25-34,35-44,45-54,55-64$, and 65 or over. The highest satisfaction is in the youngest age groups; the lowest in the oldest. In the case of distribution according to age, the chi-square characteristic of the independence test $\left(\mathrm{X}^{2}\right)$ has the value of 55.610 with 24 degrees of freedom, $\mathrm{P}<0.001$. The test strength was weakened by an insufficient number of observations in seven cells of the contingent table. Life satisfaction is significantly affected also by the marital status of the members of the sample. The highest satisfaction is declared by singles and married couples lower by divorced people, and the lowest by ones living in a partnership or widowed. In the case of distribution according to the marital status,

\footnotetext{
${ }^{1}$ By the term generativity, we can generally understand an effort to create something that reaches beyond the selfish human intentions. It is a wide scope donating blood or protecting nature, where one expects no reward in terms of reciprocity (Murgaš, 2009). This term was originally introduced by the psychologist Erik Erikson as the seventh out of eight stages of his epigenetical diagram of human life (later, his wife, Joan Erikson, developed one more stage). Erikson, E.H., Erikson, J.M. (1998) set this phase to the 30-65 age category and describe it as the time of great life surrounded by numerous friends and family members, where people take care of each other. Keyes and Ryff (1998) further add that there is a positive correlation between generativity and well-being. It is difficult to quantify generativity, especially when the research is applied to administration units. For example, Murgaš (2009) uses the data of the of activities, such as raising children, volunteering, NGO 'Liga proti rakovine' (a League Against Cancer) (to focus us on the donations to support oncological diseases prevention and treatment) to investigate the quality of life in the regions of Slovakia. In this context, generativity comprises average data provided by the people living in the region, that were collected througout several years and calculated for the regional (district) population. Murgaš and Klobučník (2016) calculated the index of the quality of life based on the dataset of unpaid blood donors on district level, provided by the Institute of Health Information and Statistics. As in the previous case, data were calculated for the district population. Blood donation in the Czech Republic is paid and the donor receives the equivalent of 7 euro per donation. At the same time, all donors are allowed to take a day off on the day of their donation and receive a small snack and reimbursement of travel expenses. The Czech society especially appreciates multiple blood donors who donate without financial compensation.
} 
the chi-square characteristic of the independence test $\left(\mathrm{X}^{2}\right)$ has the value of 71.700 with 16 degrees of freedom, $\mathrm{P}<0.001$. The test strength was weakened by an insufficient number of observations in five cells of the contingent table. In this context, it is also true, that people living with someone declared significantly higher life satisfaction than people living alone. In the case of distribution according to the number of household members, the chi-square characteristic of the independence test $\left(\mathrm{X}^{2}\right)$ has the value of 45.631 with 12 degrees of freedom, $\mathrm{P}<0.001$. The test strength was weakened by an insufficient number of observations in three cells of the contingent table.

Life satisfaction significantly increases with education. In the case of distribution according to education, the chi-square characteristic of the independence test $\left(\mathrm{X}^{2}\right)$ has the value of 91.706 with 12 degrees of freedom, $\mathrm{P}<0.001$. The test strength was weakened by an insufficient number of observations in four cells of the contingent table. In the distribution according to the size of residence, people living in smaller residences are more satisfied with their lives. In the case of distribution according to the size of residence, the chi-square characteristic of the independence test $\left(\mathrm{X}^{2}\right)$ has the value of 36.355 with 12 degrees of freedom, $\mathrm{P}$ $<0.001$. The test strength was weakened by an insufficient number of observations in six cells of the contingent table. In terms of religiosity, the members of churches or religious societies evaluate their quality of life higher than those without religion. In the case of distribution according to religiosity, the chi-square characteristic of the independence test $\left(\mathrm{X}^{2}\right)$ has the value of 20.854 with 8 degrees of freedom, $\mathrm{P}<0.001$. The test strength was weakened by an insufficient number of observations in three cells of the contingent table.

The highest correlation was manifested between the quality of life and subjectively perceived health status. People feeling healthy are more satisfied with their lives than people perceiving some health problems. In the case of subjectively perceived health status, the chisquare characteristic of the independence test $\left(\mathrm{X}^{2}\right)$ has the value of 449.177 with 16 degrees of freedom, $\mathrm{P}<0.001$. The test strength was weakened by an insufficient number of observations in five cells of the contingent table.

\section{Methods}

To compare the quality of life in the individual districts of the Czech Republic, we used a dependency graph of $\mathrm{x}$ and y. Primary data, characterising well-being, as well as secondary data, characterising quality of place expressed by the indicators of the golden standard of quality of life, all the values in all the districts, were limited by the Cantril scale 0 to 10 , where 0 means the 'worst' quality of life, and 10 the 'best' quality of life. Therefore, the individual axes in the Fig. 1 have these limit values. On the horizontal axis (x-axis), the values of the quality of a place (secondary data) and on the vertical axis (y-axis), well-being values (primary data) were applied. In mathematics, the independent variable $\mathrm{x}$ is shown in the graph on the horizontal axis and the dependent variable $\mathrm{y}$ on the vertical. The reasoning behind the application of the data of individual districts into the graph was as follows: values of the extensive research of the quality of a place, which were discussed in detail in Murgaš and Klobučník (2014), did not have any effect on the values of well-being, and therefore, were applied to the x-axis as an independent variable. On the other hand, empirical research of the 'hard data' of the quality of a place differentiated the districts of the Czech Republic according to the quality of life in these regions and could have indirectly influenced the opinion of people who expressed their satisfaction with the quality of life in the questionnaires. In other words, regions that reached high values in the quantitative research of the indicators of the golden standard of quality of life should, according to the assumptions, also achieve high values when assessing well-being.

On the contrary, the regions that achieved low values of the quality of life should, based on the satisfaction of people, also reach low values (according to well-being). Based on this viewpoint, there should be manifested some 
kind of relationship, that is, dependency between the golden standard and well-being of the quality of life expressed by a function (we assume linearity). The values on both axes could range from 0 to 10, but the actual values never reached these. Based on Fig. 1, in a narrower sense, we can say that the quality of life ranged from 2.0 to 8.0 , and the values for well-being reached from 4.0 to approximately 8.0. A direct linear dependence (positive value of $\mathrm{x}$ in the graph equation) would indicate a linear relationship, meaning that the districts that reached high values in the empirical research achieved such values also in the research of well-being. The strength or intensity of this relationship, respectively, dependence is expressed by the value before the $\mathrm{x}$ variable in the graph equation. The higher this value, the bigger the incline of the trend line and the stronger the dependence between the variables.

\section{Results}

As the real resulting values of the quality of a place and those of well-being in districts of the Czech Republic in 2014 ranged within certain intervals, for clarity, we created a graph where we can see the cut off points (Fig. 1). These are limited by the real values obtained in both pieces of research of the quality of life. The names of the individual districts can be found in Table 1 for some district numbers guidelines, which, specify their location (as some districts were grouped in one place in the graph), are used for more clarity. The districts at the trend line (or relatively close to it) are the districts from the mentioned regions that have the strongest dependency between both variables, $\mathrm{x}$ and $\mathrm{y}$, from all the analysed units.

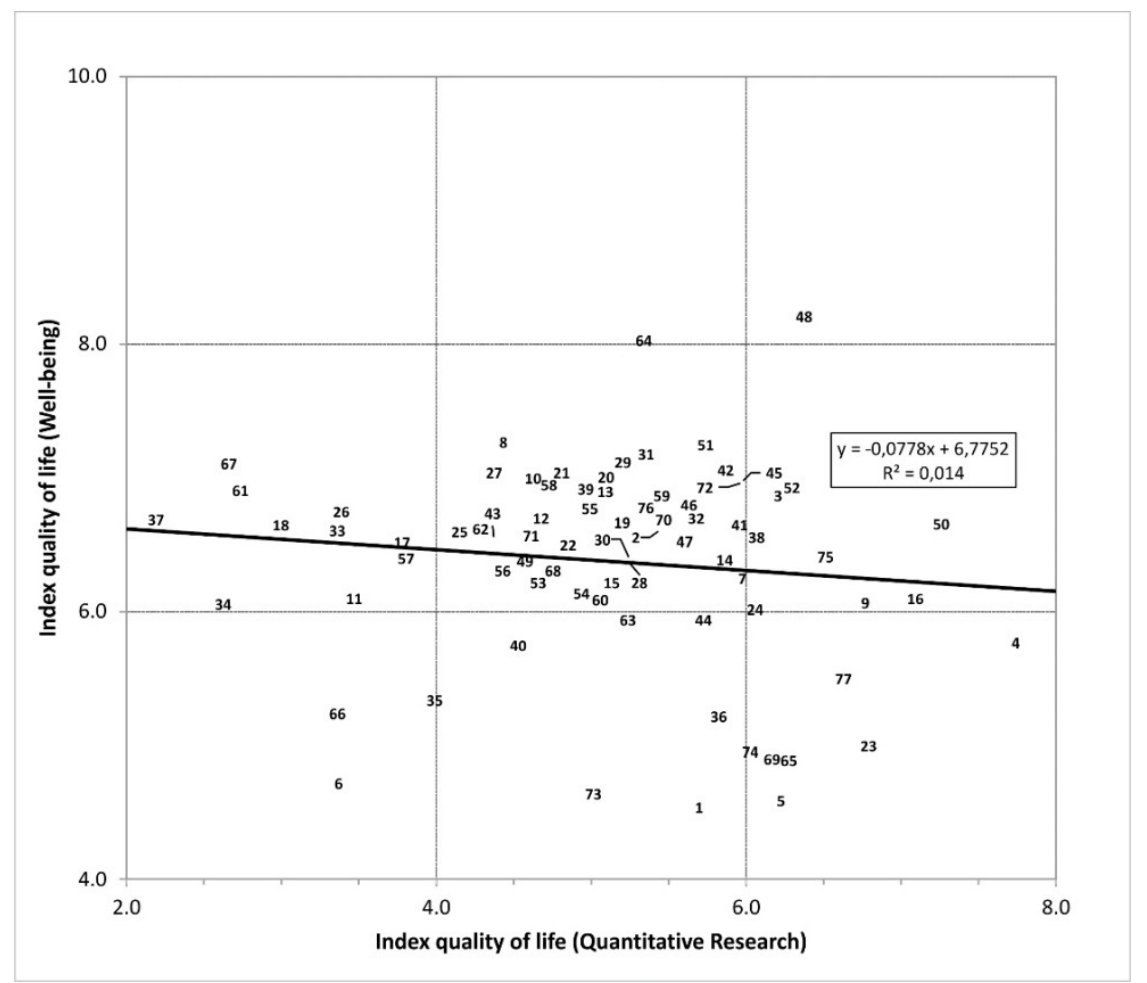

Fig. 1. The dependency between the values of quality of life of the golden standard and the values of well-being in districts of the Czech Republic in 2014 (axes ranges only with the real achieved values). 
The units that are outside the trend line (or further away from it) are the districts whose resulting values of the quality of a place and the values of well-being do not show any relationship or dependency, or only a slight one. In the end, it, thus, undermines the resulting value of the correlation dependency of all districts of the Czech Republic between the two observed variables. The Pearson correlation coefficient reached the value of -0.1183 . Based on the equation, we can find out the coefficient of the determination between both variables, which gives us the proportion of the common variance, that is, how significantly (in \%) the change of one variable influences the other one. In this case, it is $1.4 \%$, so there is only $1.4 \%$ chance that the values of well-being are dependent on the values of the empirical research of indicators of the quality of a place. Based on the linear equation of this dependency of $x$ and $y$, it is possible to calculate also the deviations from the trend line, that is, what is the difference between the values that would map them to the trend line and they would create an ideal linear relationship. This is true only in theory; in practice, we see substantial deviations (e.g., district Pilsen-city, Šumperk, etc.), see Fig. 2.

$\mathrm{T} \mathrm{a} \mathrm{b} \mathrm{le} \mathrm{1.} \mathrm{Names} \mathrm{of} \mathrm{the} \mathrm{districts} \mathrm{with} \mathrm{assigned} \mathrm{numbers} \mathrm{necessary} \mathrm{for} \mathrm{identification} \mathrm{in} \mathrm{Fig.} 1$.

\begin{tabular}{|c|c|c|c|c|c|}
\hline Num. & District & Num. & District & Num. & District \\
\hline 1 & Benešov & 21 & Jeseník & 41 & Olomouc \\
\hline 2 & Beroun & 22 & Jičín & 42 & Opava \\
\hline 3 & Blansko & 23 & Jihlava & 43 & Ostrava-město \\
\hline 4 & Brno-město & 24 & Jindř. Hradec & 44 & Pardubice \\
\hline 5 & Brno-venkov & 25 & Karlovy Vary & 45 & Pelhřimov \\
\hline 6 & Bruntál & 26 & Karviná & 46 & Písek \\
\hline 7 & Břeclav & 27 & Kladno & 47 & Plzeň-jih \\
\hline 8 & Česká Lípa & 28 & Klatovy & 48 & Plzeň-město \\
\hline 9 & České Budějovice & 29 & Kolín & 49 & Plzeň-sever \\
\hline 10 & Český Krumlov & 30 & Kroměříž & 50 & Praha \\
\hline 11 & Děčín & 31 & Kutná Hora & 51 & Praha-východ \\
\hline 12 & Domažlice & 32 & Liberec & 52 & Praha-západ \\
\hline 13 & Frýdek-Místek & 33 & Litoměřice & 53 & Prachatice \\
\hline 14 & Havlíčkův Brod & 34 & Louny & 54 & Prostějov \\
\hline 15 & Hodonín & 35 & Mělník & 55 & Přerov \\
\hline 16 & Hradec Králové & 36 & Mladá Boleslav & 56 & Příbram \\
\hline 17 & Cheb & 37 & Most & 57 & Rakovník \\
\hline 18 & Chomutov & 38 & Náchod & 58 & Rokycany \\
\hline 19 & Chrudim & 39 & Nový Jičín & 59 & Rychnov nad Kněžnou \\
\hline 20 & Jablonec nad Nisou & 40 & Nymburk & 60 & Semily \\
\hline 61 & Sokolov & 67 & Teplice & 73 & Vsetín \\
\hline 62 & Strakonice & 68 & Trutnov & 74 & Vyškov \\
\hline 63 & Svitavy & 69 & Třebíč & 75 & Zlín \\
\hline 64 & Šumperk & 70 & Uher. Hradiště & 76 & Znojmo \\
\hline 65 & Tábor & 71 & Ústí nad Labem & 77 & Ždár nad Sázavou \\
\hline 66 & Tachov & 72 & Ústí nad Orlicí & & \\
\hline
\end{tabular}




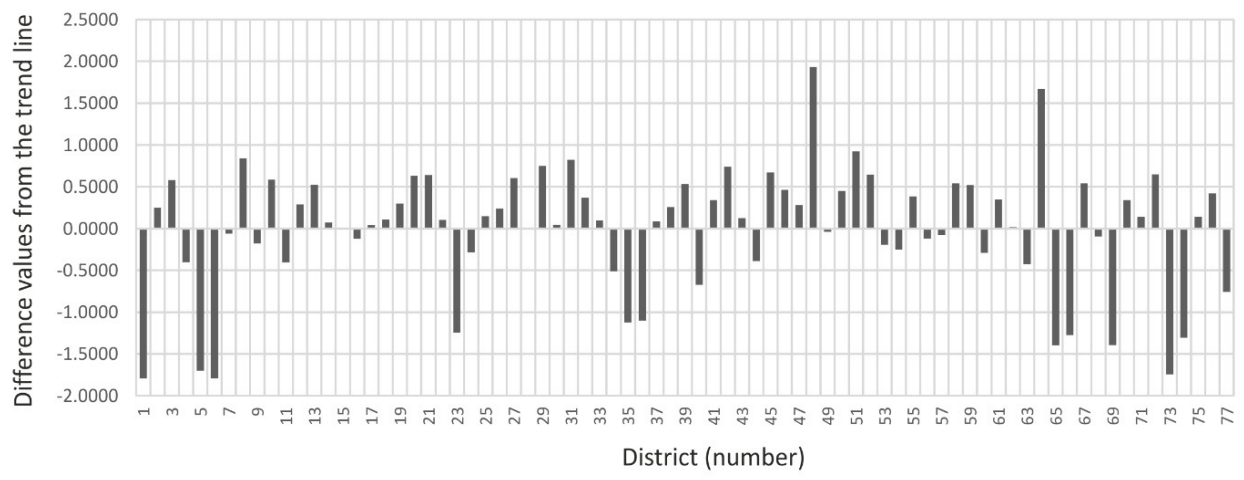

Fig. 2. The difference of values between the districts and the trend line in the dependency graph.

Since Fig. 1 has the same range of $\mathrm{x}$ and $\mathrm{y}$ axes, we can divide it into a total of 25 squares (five on the $\mathrm{x}$-axis and five on the $\mathrm{y}$-axis). The whole graph, thus, has only eight squares that include the values for the districts (well-being and also the quality of a place); this is shown in Fig. 3. The frequency of districts in the squares is then shown in Fig. 4.

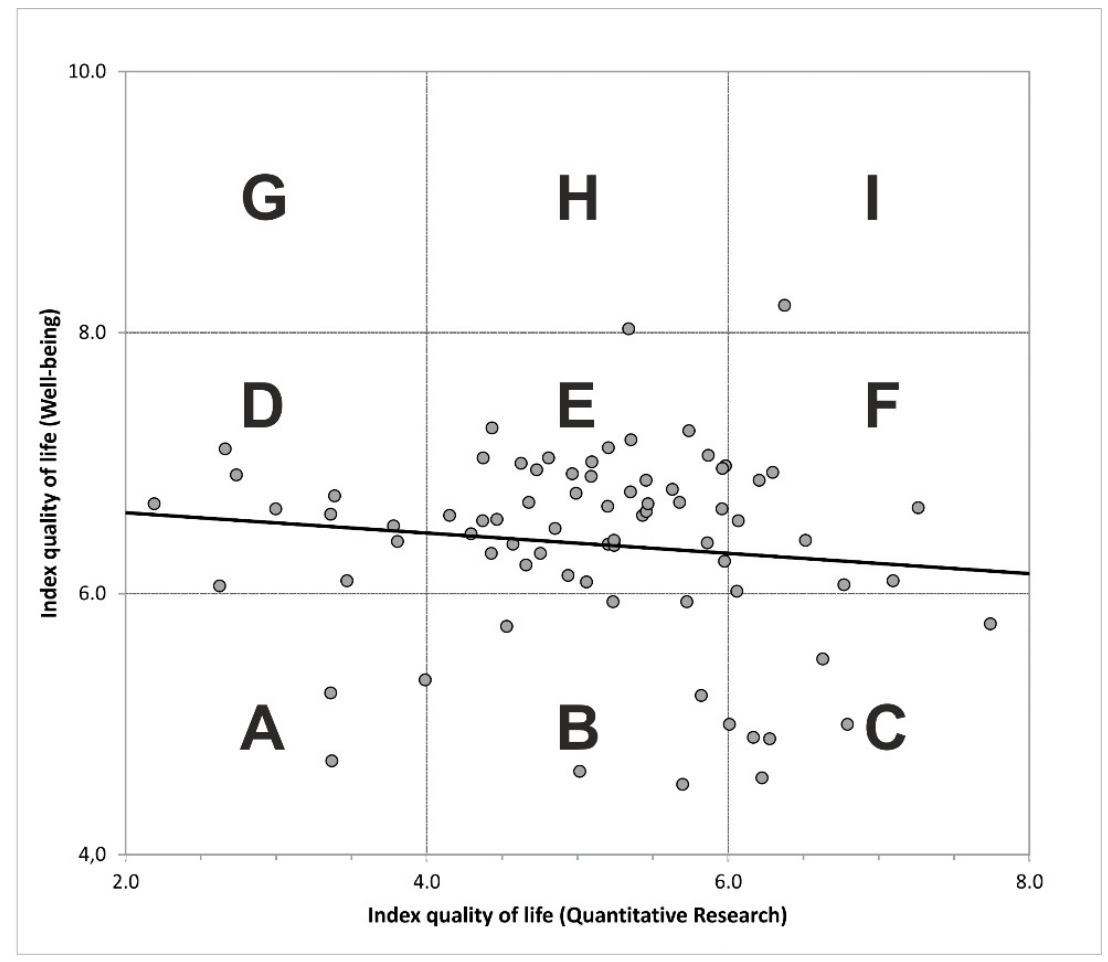

Fig. 3. Squares A- I with the values of well-being and quality of a place. 


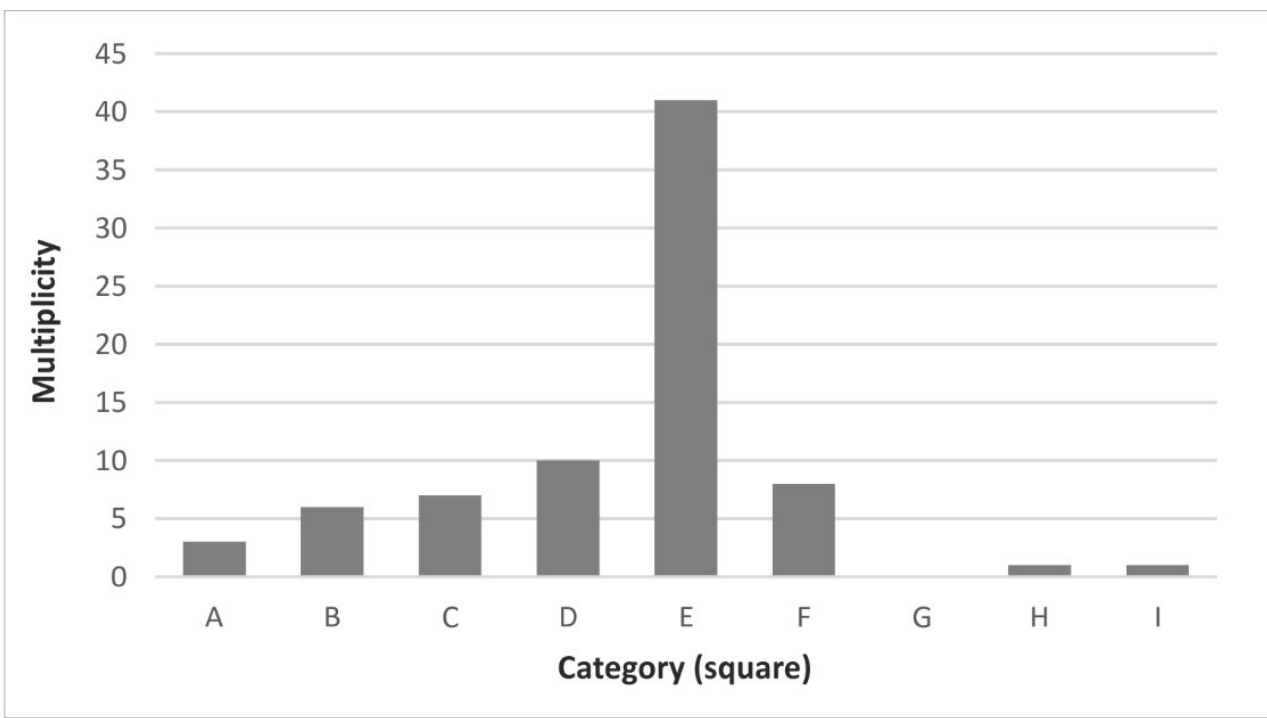

Fig. 4. Frequency of districts in individual categories (squares with the values of quality of life in districts, well-being, and the golden standard).

Districts can be divided into five groups according to their position in relation to the trend line. The first group consists of 26 districts (31\% of the total number of districts) lying very close to the trend line or at a slight distance from it $( \pm 0.25)$. For these districts, it is true that the well-being of the inhabitants, whatever its value at the Cantril scale $0-10$, has an almost linear relationship with the quality of a place in the districts they live in. The second group includes 29 districts (38\%) that lie below the trend line (Fig. 2) at a distance of 0.261.0. The third group consists of two districts (3\%) - Pilsen-city and Šmperk - with values of well-being significantly higher than the values of the quality of a place. These districts lie above the trend line (Fig. 2) at a distance of more than 1.0. The fourth group consists of nine districts (12\%) that lie under the trend line (Fig. 2) at a distance of 0.26-1.0. The fifth group includes 11 districts (14\%) lying under the trend line (Fig. 2) at a distance of more than 1.0. According to Fig. 2 and Fig. 4, the majority - 41 districts (53\%) - lie in the central square E of the matrix, limited by the values of well-being quality (6.0 and 8.0) and values of the quality of a place (4.0 and 6.0).

From the spatial point of view, we constructed two maps that show the difference between well-being and the quality of a place at the district level. The maps then show absolute values between these two variables, which show whether people greatly overestimated or underestimated their region with their attitudes compared with the calculated values (great values of differences), or their attitudes approached the calculated quality of life in the specific districts of the Czech Republic. We divided them into two categories. On one hand, we studied the districts where the values of well-being were higher than the values of the quality 
of a place (Fig. 5) and then the districts where the values of well-being were lower than the achieved values of the quality of a place (Fig. 6). It is evident that in the majority of districts of the Czech Republic, people assessed their places of residence (districts they live in) much higher than the districts achieved in the research.

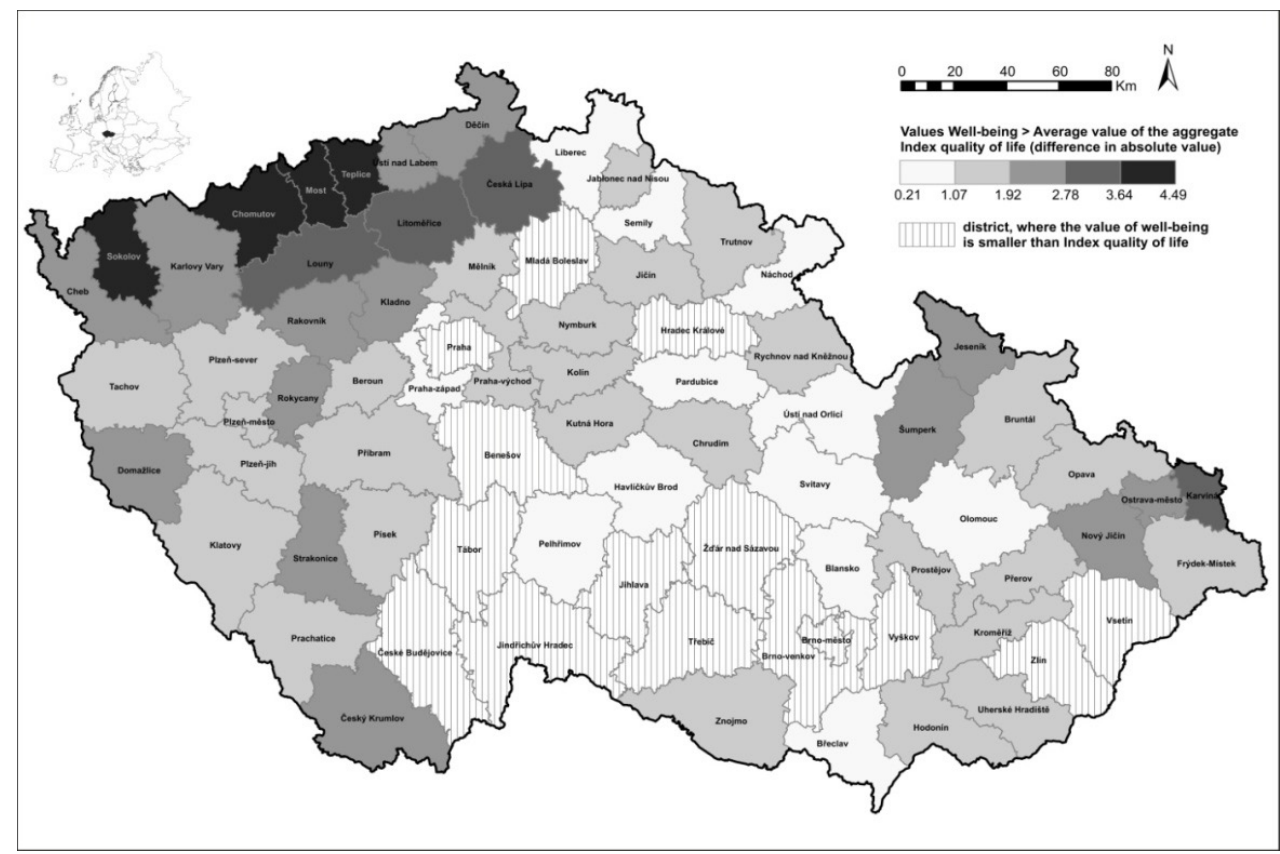

Fig. 5. Comparison between the values of well-being and the Index of the quality of life (the well-being values are higher than the values of the quality of a place) in the districts of the Czech Republic.

The main result of the analysis of the comparison of the data quantifying the quality of a place at the level of districts in the Czech Republic with the data on the well-being of the residents of these districts, and thus, the answer to the question in the title of the article does the quality of a place affect well-being - is that it does not, or rather; it does, but only slightly. The Pearson correlation coefficient of well-being and quality of a place reached the value of -0.1183 . Thus, the hypothesis that the quality of a place does not affect well-being has been confirmed. From the methodological aspect, we can consider to be legitimate the knowledge that the objective dimension of quality of life conceptualised as the optimal external conditions of 'quality of life as what is supposed to be' and quantified by the indicators of the golden standard of quality of life does not correlate with well-being, that is, the subjective dimension.

These statements need to be confirmed by further research. If they are confirmed, it would imply an important conclusion for the academic and decision-making spheres. The major- 


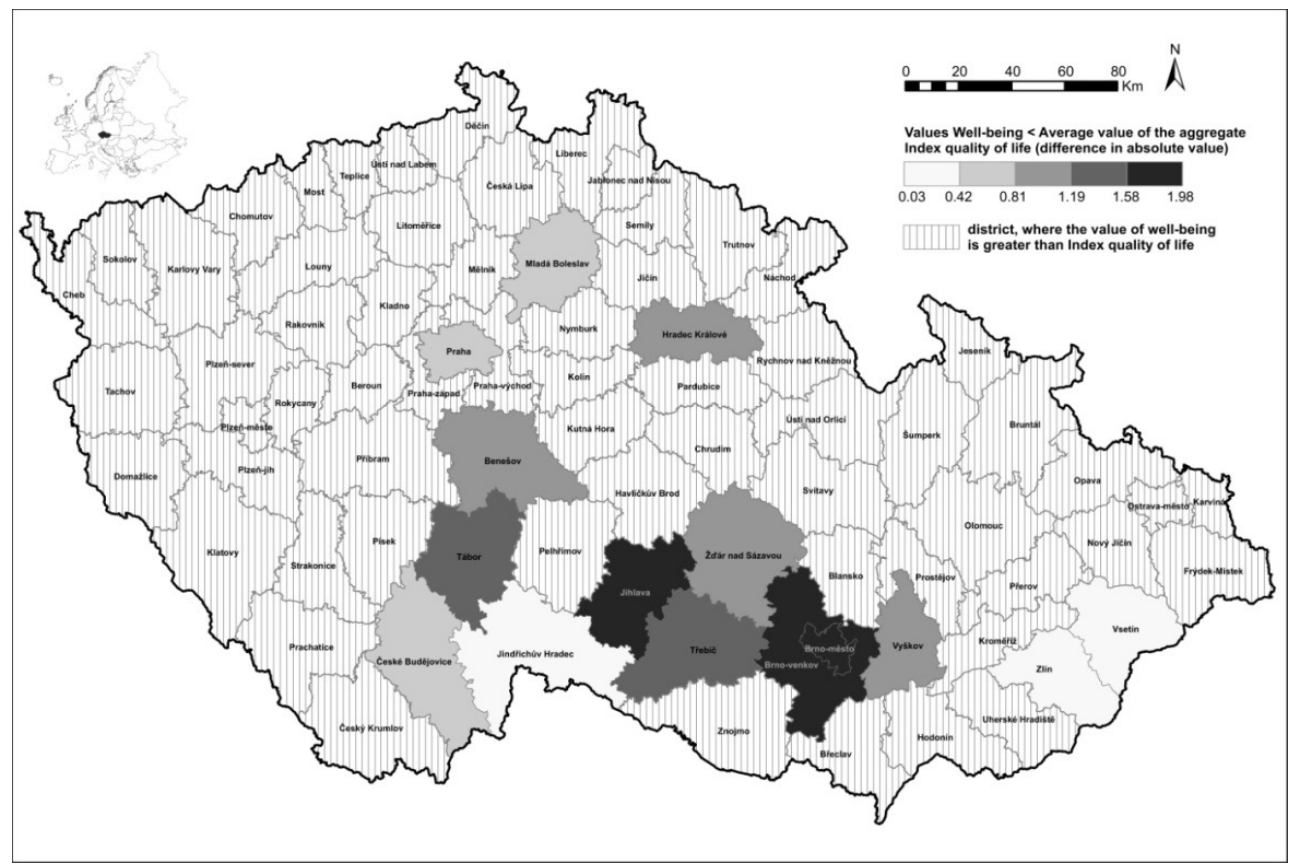

Fig. 6. Comparison between the values of well-being and the Index of the quality of life (the well-being values are lower than the values of the quality of a place) in the districts of the Czech Republic.

ity of the population of the Czech Republic (62 out of 77 districts) assesses their well-being higher than the value of the quality of a place they live in. At the same time, in 15 districts, including the city districts of Prague and Brno, the residents assess the level of their wellbeing lower than their quality of a place. This is remarkable especially in case of Brno, with the quality of a place ranking as one of the fifteen highest rated municipalities from all the 6,251 municipalities in the Czech Republic (Murgaš, Klobučník, 2016). The future research needs to be focussed on the clarification of these facts.

The fact that at district level, the quality of a place has just a little (and even negative) impact on the well-being is valid across the urban-rural continuum. Table 2 shows the 10 most populated districts as well as the most populated cities, which are, in fact, district centres. Among these, we can also find four city districts (Praha, Brno, Ostrava, and Plzeň) with the highest urbanisation level. On the contrary, Table 3 represents the lowest populated districts. Well-being in the two largest cities (Praha and Brno) and three districts (Brno-venkov, Zlín and České Budejovice) does not reach the values of the quality of a place, which means that their inhabitants are not as satisfied as they are supposed to be according to statistical data. In other district centres, both small and large, the values of well-being exceed the quality of life, which means that unlike the previous case, the population tends to be more satisfied despite the lower quality of place. Generally, rural areas in the Czech Republic have slightly higher 
values of the Index of the quality of life (5.31) than their urban counterparts (5.14). It is the small rural villages that occupy the position on both poles - the smallest and highest values of the Index of the quality of life. An exception among the most populated cities is Brno, which is ranked $10^{\text {th }}$ place with the Index of the quality of life at 7.74. When taking into account the size categories, the highest values of the Index of the quality of life were in the five largest cities with a population over 100,000. On the other hand, the city of Ostrava, which is the third largest city in the Czech Republic with the population of 302 thousand, ranks among all 6,251 municipalities to the $5327^{\text {th }}$ place with the index 4.17 (Murgaš, Klobučník, 2016). From the aforementioned data, it is thus obvious that on a relatively small Czech territory, a rural-urban dichotomy does not occur in the correlation between the quality of life and the quality of a place.

T a b l e 2. Comparison between well-being and the quality of a place in the most populated districts (2011).

\begin{tabular}{|l|r|l|l|l|l|}
\hline District & $\begin{array}{l}\text { District } \\
\text { population }\end{array}$ & Centre of district & $\begin{array}{l}\text { Population of } \\
\text { district centre }\end{array}$ & $\begin{array}{l}\text { Comparison between } \\
\text { well-being and the quality } \\
\text { of a place }\end{array}$ & $\begin{array}{l}\text { Value } \\
\text { (difference) }\end{array}$ \\
\hline Praha & $1,234,037$ & Praha & $1,234,037$ & well-being is lower & -0.6002 \\
\hline Brno-city & 379,871 & Brno & 379,871 & well-being is lower & -1.9700 \\
\hline Ostrava-city & 331,825 & Ostrava & 301,942 & well-being is higher & 2.1891 \\
\hline Karviná & 265,264 & Karviná & 59,698 & well-being is higher & 3.3623 \\
\hline Olomouc & 231,445 & Olomouc & 99,527 & well-being is higher & 0.6911 \\
\hline Frýdek-Místek & 211,392 & Frýdek-Místek & 58,091 & well-being is higher & 1.8094 \\
\hline Brno-venkov & 203,858 & Brno & 379,871 & well-being is lower & -1.6347 \\
\hline Zlín & 193,125 & Zlín & 75,875 & well-being is lower & -0.1030 \\
\hline České Budějovice & 186,415 & České Budějovice & 93,639 & well-being is lower & -0.6982 \\
\hline Plzeň-city & 184,849 & Plzeň & 167,648 & well-being is higher & 1.8353 \\
\hline
\end{tabular}

Source: Authors' research, Czech Statistical Office - https://www.czso.cz/csu/czso/domov

$\mathrm{T} \mathrm{a} \mathrm{b} \mathrm{l} \mathrm{e} \mathrm{3.} \mathrm{Comparison} \mathrm{between} \mathrm{well-being} \mathrm{and} \mathrm{the} \mathrm{quality} \mathrm{of} \mathrm{a} \mathrm{place} \mathrm{in} \mathrm{the} \mathrm{least} \mathrm{populated} \mathrm{districts} \mathrm{(2011).}$

\begin{tabular}{|l|l|l|l|l|l|}
\hline District & $\begin{array}{l}\text { District } \\
\text { population }\end{array}$ & Centre of district & $\begin{array}{l}\text { Population of } \\
\text { district centre }\end{array}$ & $\begin{array}{l}\text { Comparison between } \\
\text { well-being and the } \\
\text { quality of a place }\end{array}$ & $\begin{array}{l}\text { Value } \\
\text { (difference) }\end{array}$ \\
\hline Jeseník & 40,691 & Jeseník & 11,897 & well-being is higher & 2.2322 \\
\hline Rokycany & 47,587 & Rokycany & 14,097 & well-being is higher & 2.2218 \\
\hline Prachatice & 51,169 & Prachatice & 11,432 & well-being is higher & 1.5625 \\
\hline Tachov & 53,299 & Tachov & 12,721 & well-being is higher & 1.8787 \\
\hline Rakovník & 55,493 & Rakovník & 16,748 & well-being is higher & 2.5958 \\
\hline Domažlice & 60,655 & Domažlice & 11,037 & well-being is higher & 2.0235 \\
\hline Český Krumlov & 61,567 & Český Krumlov & 13,478 & well-being is higher & 2.3745 \\
\hline Plzeň-jih & 61,929 & Plzeň & 167,648 & well-being is higher & 1.1741 \\
\hline Písek & 70,388 & Písek & 29,641 & well-being is higher & 1.1704 \\
\hline Strakonice & 70,879 & Strakonice & 23,065 & well-being is higher & 2.1665 \\
\hline
\end{tabular}

Source: Authors' research, Czech Statistical Office - https://www.czso.cz/csu/czso/domov 


\section{Conclusion}

This article aimed to analyse the impact that the quality of a place might have on well-being. With the use of the Pearson correlation coefficient, selected data of well-being were quantified on a hierarchical level of districts in the Czech Republic. The result of such quantification is the value of the Pearson correlation coefficient of the variables' well-being and the quality of a place at -0.1183 . Using the coefficient of determination between both variables, which gives the proportion of the common variance, it was found that change of one variable affects the other one in $1.4 \%$ districts.

As a result, several significant conclusions can be drawn. (i) Our hypothesis that the quality of a place does not influence well-being to a larger extent proved to be valid. The quality of a place negatively affects the well-being, however, to a lesser extent. (ii) The Pearson correlation coefficient and coefficient of determination reach lower values than those reported by Lyubomirsky et al. (2005) and Blatný (2010). (iii) The fact that the quality of a place influences well-being does not seems to be related to the size of district centre (Tables 2 and 3) or even to a rural-urban dichotomy. (iv) A rough consensus between the quality of a place and well-being can be seen only in the case of two districts out of 77 (districts Jindřichův Hradec and Zlín). (v) In 62 districts, the inhabitants evaluated their well-being as better than the quality of the place in which they live. It is interesting that among these districts, we can find north-west districts and even one north-east district, where the evaluated quality of a place was the lowest in the Czech Republic (Murgaš, Klobučník, 2016). (vi) At the same time, the population of 13 districts, including city districts of the capital city Prague and the second largest city Brno, think that their well-being is worse than the quality of the place in which they live. It is remarkable particularly in the case of Brno, where the quality of a place is ranked $10^{\text {th }}$ place out of all 6251 settlements in the Czech Republic (Murgaš, Klobučník, 2016). (vii) From the geographical point of view, a specific feature can be seen in the compact spatial distribution of districts with the lowest quality of well-being and the quality of a place (districts in the south of the Czech Republic). (viii) Another geographical curiosity is the differences in neighbouring districts Hradec Králové and Pardubice. Although both cities of approximately the same size are the seats of higher territorial units, the quality of well-being exceeds the quality of a place in district Pardubice, while in district Hradec Králové the value of the quality of well-being is lower than the value of the quality of a place. It is recommended that a further research focus should be to clarify the facts and provide explanation of such processes.

\section{Acknowledgements}

This paper was supported by the SGS grant of Faculty of Science, Humanities and Education Technical University of Liberec, project No 21105 and the research project APVV-0018-12 'Human geography and demography interactions, nodes and contradictions in time-space network'

We would like to express our very great appreciation to Mrs. Catherine E. Dimmock-Benko, B.Ed, M.A, external teacher at the Department of Languages, for her willingness to provide the linguistic correction of this article, and also wish to thank the anonymous referees for their inspiring comments and suggestions on the earlier draft of this article.

\section{References}

Andráško, I. (2013). Quality of life: an introduction to the concept. Brno: Masarykova univerzita. Angelovič, M. (2013). Spokojnost’ s miestom ako indikátor kvality života v prihraničných obciach slovensko- 
ukrajinskej hranice. In Kvalita života 2013, sborník příspěvků z mezinárodní konference 4.-5.12.2013 v Liberci, (pp. 8-17). Liberec: Technická univerzita v Liberci.

Angelovič, M. \& Ištok R. (2016). How to assess quality of life. Theoretical and methodological research aspects in cross-boirder regions. Bulletin of Geography. Socio-economic Series, 32, 19-32. DOI: 10.1515/bog-2016-0012.

Aslam, A. \& Corrado L. (2012). The geography of well-being. Journal of Economic Geography, 12(3), 627-649. DOI: $10.1093 /$ jeg/lbr041.

Blatný, M. (2010). Personal well-being (in Czech). In M. Blatný et al. (Eds.), Psychologie osobnosti: hlavní témata, současné prístupy (pp. 197-212). Praha: GRADA.

Casas, F., Figuer, M., Gonzáles, M. \& Coenders G. (2004). Satisfaction with life domains and salient values for the future. Analyses about children and their parents. In W. Glatzer, von S. Bellow \& M. Stofferegen (Eds.), Challenges for quality of life in the contemporary world. Advances in quality-of-life studies, theory and research (pp. 233-248). Dordrecht: Springer.

Davern, M. (2014). Geographic information systems and subjective well-being. In A.C. Michalos (Ed.), Encyclopedia of quality of life and well-being research (pp. 2524-2538). Dordrecht: Springer.

Diener, E. \& Biswas-Diener R. (2008). Happiness. Unlocking the mysteries of psychological wealth. Malden: Blackwell.

Dutt, A.K. \& Radcliff B. (Eds.) (2009). Happiness, economics and politics: towards a multi-disciplinary approach. Cheltenham: Edward Elgar Publishing.

Easterlin, R. A. (2009). Lost in transition: Life satisfaction on the road to capitalism. Journal of Economic Behavior \& Organization, 71(2), 130-145. DOI: 10.1016/j.jebo.2009.04.003.

Easterlin, R.A. (2015). Happiness and economic growth - the evidence. In W. Glatzer, L. Camfield, V. Møller \& M. Rojas (Eds.), Global handbook of quality of life. Exploration of well-beings of nations and continents (pp. 283-300). Dordrecht: Springer.

Erikson, E.H. \& Erikson J.M. (1998). The life cycle completed (extended version). New York (NY): W. W. Norton \& Company.

Eurostat (2015). Unemployment statistics. http://ec.europa.eu/eurostat/statistics-explained/index.php/unemployment_statistics. Accessed September 22, 2015.

Eyles, J. \& Wiliams A. (2008). Sense of place, health and quality of life. Aldershot: Ashgate.

Florida, R. (2012). What draws creative people? Quality of Place. Urbanland, The Magazine of the Urbanland Institute. http://urbanland.uli.org/industrysectors/what-draws-creative-peo ple-quality-of-place/. Accessed 4. April 4, 2016.

Francis, P. (2015). Laudato si'. On care for our common home. Vatican City: Libreria Editrice Vaticana.

Ira, V., Michálek, A. \& Podolák P. (2008). Evaluation of the Territorial Disparities in Selected Aspects of Life Quality in Slovakia. In Regional disparities in Central Europe (pp. 157-179). Bratislava: Slovenská komisia pre UNESCO, NK-MOST Sociologický ústav SAV.

Ira, V. (2011). Udržatelnost' a kvalita života v geografických výskumoch. In: Cesty k udržatelnejšej budúcnosti (Dobřišs vo svetle geografických a environmentálnych výskumov) (pp. 70-77). Bratislava: Geografický ústav SAV, Slovenská geografická spoločnost’ pri SAV, STUŽ/SR.

Ira, V. (2013). Dvacet let po rozdělení: Kvalita života v Česku a na Slovensku. Geografické Rozhledy, 22(3), 8-9.

Ira, V. (2015). Petržalka a kvalita života jej obyvatelov (subjektívna dimenzia hodnotenia). Životné Prostredie, 49(2), 82-86.

Jakubcová, A., Grežo, H., Hrešková, A. \& Petrovič F. (2016). Impacts of flooding on the quality of life in rural regions of Southern Slovakia. Applied Research in Quality of Life, 11(1), 221-238. DOI: 10.1007/s11482-014-9363-x.

Keyes, C.L.M. \& Ryff C.D. (1998). Generativity in adult lives: Social structural contours and quality of life consequences. In D. P. McAdams \& E. de St. Aubin (Eds.), Generativity and adult development: Psychosocial perspectives on caring for and Contributing to the next generation (pp. 227-263). Washington, DC: American Psychological Association Press.

Lyubomirsky, S., Sheldon, K.M. \& Schkade D. (2005). Pursuing happiness: The architecture of sustainable change. Review of General Psychology, 9(2),111-131. DOI: 10.1037/1089-2680.9.2.111.

Muchová, Z. \& Petrovič F. (2010). Changes in the landscape due to land consolidations. Ekológia (Bratislava), 29(2), 140-157. DOI: 10.4149/ekol_2010_02_140.

Murgaš, F. (2009). Kvalita života a jej priestorová diferenciácia v okresoch Slovenska (in Slovak). Quality of life and its spatial differentiation in Slovakia. Geografický Časopis, 61(2), 121-138.

Murgaš, F. (2013). Několik poznámek ke kvalitě urbánního života. In: Kvalita života 2013, sborník přispěvků $z$ mezinárodní konference 4. a 5. 12. 2013 v Liberci (pp. 97-116). Liberec: Technická univerzita v Liberci. 
Murgaš, F. (2014). Kvalita urbánního života jako holistický koncept. Př́padová studie Liberec. Liberec: Technická univerzita v Liberci.

Murgaš, F. (2015). Kvalita života jako náhrada obecné míry socio-ekonomického rozvoje v podobě HDP. In Kvalita života 2015, sborník př́spěvků z česko-slovenské konference 2. a 3. 12. 2015 v Liberci ( pp. 62-75). Liberec: Technická univerzita v Liberci.

Murgaš, F. \& Klobučník M. (2016). Municipalities and regions as good places to live: Index of quality of life in the Czech Republic. Applied Research Quality Life, 9, 1-18. DOI: 10.1007/s11482-014-9381-8.

Rabušic, L. \& Hamanová J. (2009). Hodnoty a postoje v ČR 1991-2008 (pramenná publikace European Values Study). Brno: Masarykova univerzita.

Rapley, M. (2008). Quality of life research. A critical introduction. SAGE: London.

Rappaport, J. (2009). The increasing importance of quality of life. Journal of Economic Geography, 9(6), 779-804. DOI: $10.1093 / \mathrm{jeg} / \mathrm{lbp} 009$.

Sanfey, P. \& Teksoz U. (2005). Does transition make you happy? Working Paper No. 91. London: European Bank for Reconstruction and Development.

Seligman, M. (2002). Authentic happiness: Using the new positive psychology to realize your potential for lasting fulfillment. New York: Free Press.

Sirgy, M.J. (2012). The psychology of quality of life: Hedonic well-being, life satisfaction, and eudaimonia. Dordrecht: Springer.

Stiglitz, J.E., Sen, A. \& Fitoussi J.-P. (2010). Mismeasuring our lives. Why GDP doesn't add up. London and New York: The New Press.

Trip, J.J. (2007). Assessing quality of place: A comparative analysis of Amsterdam and Rotterdam. Journal of Urban Affairs, 29(5), 501-517. DOI: 10.1111/j.1467-9906.2007.00362.x.

Veenhoven, R. (2011). Greater happiness for a greater number: Is that possible? If so, how? In K.M. Sheldon, T.B. Kashdan \& M.F. Steger (Eds.), Designing positive psychology: Taking stock and moving forward' (pp. 396-409). New York: Oxford University Press. 